\title{
PENGEMBANGAN MEDIA POHON PINTAR BERBASIS MULTIMEDIA DALAM MODEL PEMBELAJARAN CIRC UNTUK MENINGKATKAN KEMAMPUAN MENULIS PUISI PADA SISWA KELAS V SEKOLAH DASAR
}

\author{
Nurun Nisa'ul Lil Muttaqin \\ Mahasiswa Program Pascasarjana, Prodi Pendidikan Dasar, Universitas Negeri Surabaya \\ e-mail: nurunnisa0211@gmail.com
}

Received : Juli 2017

Reviewed: Agustus 2017

Accepted : September 2017

Published : September 2017

\section{ABSTRACT}

This experiments are based on an elementary school's student who has difficult in writing a poem, low in a poem, has difficult to creat and an imagination, less to understand between write a poem and description it. Because that, it needs some ways to develop in writing an poem by the student. Someone of them with arrange the learning media that can be make interest for the student to understanding the lesson and to applying a writing poem. This experiment pupose is for making a description development of smart tree (pohon pintar) media by multimeddia bassis in a learning CIRC for growing the writing poem skill for the fifth grade elementary school student. The quality of smart tree media product and how it use in the class. This developing experiment are based on the foru-D developing model that consists of first steps (1) define; (2) design; (3) develop; and (4) disseminate. But, this experiment until in develop step only without to do the disseminate step because this experiment product just use for the trying special school. The grouping of datta is doing by kelitatif-kuantitatif of descriptif. Based on experiment result is getting the good prosentase of the content, the mean learning, and the technic regularly is 95\%; 94\%; and 95,4\%. All of those aspects are including in quality aspect (very good/well). The getting observation for the teacher and student activity continually are $96,6 \%$ dan 95,8\%. Respons of the teacher and student for smart tree media is $96,8 \%$ and $94,2 \%$. The total of students study result is 84,4 which avaluable with the success criteria is 75. Based on the result of an experiment shows that smart tree media by multimeddia bassis in a CIRC learning way that has developing is good to use in writing a poem learning.

Key Words: development of Smart Tree by Multimeddia Bassis, The CIRC Learning Moddel, Writing a Poem.

\section{ABSTRAK}

Penelitian ini berdasar kenyataan bahwa siswa Sekolah Dasar yang kesulitan dalam menulis puisi, rendahnya minat berpuisi, mengalami kesulitan menuangkan pikiran dan berimajinasi, kurang memahami perbedaan menulis deskripsi dan puisi. Oleh karena itu diperlukan upaya untuk meningkatkan kemampuan menulis puisi siswa. Salah satunya dengan merancang media pembelajaran yang dapat menarik minat siswa untuk memahami materi dan mengaplikasikannya dalam menulis puisi. Tujuan dari penelitian ini adalah mendeskripsikan proses pengembangan dan kualitas media pohon pintar berbasis multimedia dalam model pembelajaran CIRC untuk meningkatkan kemampuan menulis puisi pada siswa kelas V Sekolah Dasar. Kualitas media pohon pintar yang dikembangkan ditinjau berdasarkan produk dan penggunaannya di kelas. Penelitian pengembangan ini mengacu pada model pengembangan four-D yang terdiri atas tahap (1) pendefinisian; (2) perancangan; (3) pengembangan; dan (4) penyebaran. Akan tetapi, penelitian ini hanya sampai pada tahap pengembangan tanpa melakukan penyebaran karena produk penelitian ini hanya dikhususkan sekolah uji coba. Pengumpulan data dilakukan menggunakan teknik dokumentasi, observasi, angket, dan tes. Data yang diperoleh dianalisis secara deskriptif kualitatif-kuantitatif. Berdasarkan hasil penelitian diperoleh hasil 
presentase kelayakan isi, pembelajaran, dan teknik secara berturut-turut sebesar 95\%; 94\%; dan 95,4\%. Semua kategori tersebut termasuk kategori berkualitas (sangat baik/layak). Perolehan hasil observasi terhadap aktivitas guru dan siswa berturut-turut adalah 96,6\% dan 95,8\%. Respon guru dan siswa terhadap media pohon pintar adalah 96,8\% dan 94,2\%. Rata-rata hasil belajar siswa sebesar 84,4 yang sesuai dengan kriteria ketuntasan yaitu 75. Berdasarkan hasil penelitian menunjukkan bahwa media pohon pintar berbasis multimedia dalam model pembelajaran CIRC yang dikembangkan baik digunakan pada pembelajaran menulis puisi.

Kata-Kata Kunci: Pengembangan Media Pohon Pintar Berbasis Multimedia, Model Pembelajaran CIRC, Menulis Puisi.

\section{PENDAHULUAN}

Kurikulum 2013 bertujuan untuk mempersiapkan manusia Indonesia agar memiliki kemampuan hidup sebagai pribadi dan warga negara yang beriman, produktif, kreatif, inovatif, dan afektif serta mampu berkontribusi pada kehidupan bermasyarakat, berbangsa, bernegara, dan peradaban dunia. Kurikulum 2013 menekankan pada dimensi pedagogik modern dalam pembelajaran yaitu menggunakan pendekatan ilmiah. Pendekatan ilmiah (scientific approach) dalam pembelajaran sebagaimana dimaksud meliputi mengamati, menanya, menalar, mencoba, dan membentuk jejaring untuk semua mata pelajaran. Pembelajaran Bahasa Indonesia diarahkan untuk meningkatkan kemampuan peserta didik untuk berkomunikasi dalam bahasa Indonesia dengan baik dan benar, baik secara lisan maupun tulis, serta menumbuhkan rasa ingin tahu terhadap hasil karya kesastraan manusia Indonesia. Keterampilan berbahasa Indonesia mencakup empat aspek, yaitu keterampilan menyimak, keterampilan berbicara, keterampilan membaca dan keterampilan menulis. Hunley (2007) mengatakan:

"Poetry writing teachers would do well to devote a fraction of their class time to (1) helping students memorize their own poetry and poems by others, (2) helping students consciously think of ways to make their own poems more memorable, and (3) helping students find ways to tap their memories while composing new work. Require students to memorize a poem or two of their own choice as part of their grade."

Dalam pengajaran menulis puisi menyediakan sebagian kecil dari waktu kelas karena menulis puisi membutuhkan waktu lebih banyak untuk menggali gagasan dan mempertimbangkan ketepatan bahasanya (sebagai penulis pemula). Kecepatan pengungkapan gagasan harus didukung oleh ketepatan bahasa sastra yang digunakan. Menulis puisi merupakan salah satu kompetensi yang harus dikuasai siswa kelas V. Namun, siswa kurang berminat pada pembelajaran menulis puisi. Siswa mengalami kesulitan menuangkan pikiran dan perasaannya dalam bentuk puisi. Mereka kurang tertarik, merasa kesulitan dalam menuangkan gagasan/ide ke dalam larik-larik puisi, menemukan kata pertama dalam puisinya, kurang memiliki perbendaharaan kata yang memadai, kurang dapat memilih kata-kata dengan tepat serta kurang memahami bagaimana merangkaikan kata-kata ke dalam sebuah puisi karena tidak terbisaa mengemukakan perasaan, pemikiran, dan imajinasi.

Hambatan lain adalah, bahwa guru masih melaksanakan penilaian yang bersifat teoretis (berupa pengetahuan dan pemahaman konsep) saja. Jadi pada pembelajaran kompetensi menulis puisi, guru lebih cenderung mengevaluasi hal-hal yang berkaitan dengan teori puisi, misalnya bentuk-bentuk puisi, jenis-jenis puisi, unsur-unsur pembangun puisi (baik unsur intrinsik maupun unsur ekstrinsik). Bagaimana siswa menuangkan ide gagasannya ke dalam bentuk puisi masih terabaikan oleh guru. Siswa kurang mendapat kesempatan untuk melakukan konstruksi pengetahuan dan melakukan pengembangan pengetahuan itu menjadi sebuah produk pengetahuan baru. Kondisi demikian, hampir dihadapi oleh guru yang mengajarkan Bahasa Indonesia. Namun demikian, hal itu bukan tanpa alasan. Ada beberapa faktor yang menyebabkan pembelajaran menulis puisi tidak dapat dilaksanakan dengan baik. Pertama, tidak semua guru bahasa memiliki kegemaran terhadap materi menulis puisi. Kedua, mengajarkan menulis puisi bukan hanya berkaitan dengan kemampuan menggunakan bahasa tetapi, juga berhubungan dengan panggilan perasaan, norma, dan nilainilai estetika dalam bentuk media bahasa. Ketiga, sikap berpikir inovatif dan kreatif yang belum tumbuh pada guru sebagai upaya untuk mengembangkan diri.

Gerlach \& Ely (1980) mengungkapkan bahwa media pembelajaran memiliki cakupan yang sangat luas, yaitu termasuk manusia, materi atau kajian yang membangun 
suatu kondisi yang membuat peserta didik mampu memperoleh pengetahuan, keterampilan atau sikap. Media pembelajaran mencakup semua sumber yang diperlukan untuk melakukan komunikasi dalam pembelajaran, sehingga bentuknya bisa berupa perangkat keras (hardware), seperti computer, TV, projector, dan perangkat lunak (software) yang digunakan pada perangkat keras itu. Media pembelajaran dapat meningkatkan motivasi siswa dalam menciptakan suasana belajar secara kolaboratif, dan membuat siswa aktif. Salah satu media pembelajaran yang dapat meningkatkan aktivitas siswa adalah media pohon pintar berbasis multimedia.

Pembelajaran di kelas masih menggunakan media pembelajaran konvensional atau manual. Hal ini disebabkan masih banyak guru yang belum mahir dalam menggunakan alat komputer maupun internet. Penelitian ini berbeda dengan penelitian tersebut, sebab media pohon pintar dalam penelitian ini dikemas menggunakan multimedia yang dikembangkan dalam model pembelajaran CIRC. Steven dan Slavin (dalam Nur, 2000:8) berpendapat bahwa model CIRC merupakan sebuah program komprehensif atau luas dan lengkap untuk pengajaran membaca dan menulis untuk kelas-kelas tinggi sekolah dasar. Dalam penelitian ini diharapkan para siswa dapat meningkatkan cara berfikir kritis, kreatif dan menumbuhkan rasa sosial yang tinggi.

Untuk mencapai harapan tersebut, peneliti menggunakan media pohon pintar berbasis multimedia dalam pembelajaran menulis puisi. Hal itu mendukung peneliti untuk memilih judul penelitian "Pengembangan Media Pohon Pintar berbasis Multimedia dalam Model Pembelajaran CIRC untuk Meningkatkan Kemampuan Menulis Puisi pada Siswa Kelas V Sekolah Dasar".

\section{KAJIAN PUSTAKA}

\section{Kemampuan Menulis Puisi}

Menurut Tarigan (1994:3) menulis merupakan suatu keterampilan berbahasa yang dipergunakan untuk berkomunikasi secara tidak langsung, tidak secara tatap muka dengan orang lain. Menulis merupakan suatu kegiatan yang produktif dan ekspresif.

Menulis dapat dianggap sebagai suatu proses maupun suatu hasil. Menulis merupakan kegiatan yang dilakukan oleh seseorang untuk menghasilkan sebuah tulisan. Menurut Heaton, (dalam Slamet, 2008:141) menulis merupakan keterampilan yang sukar dan kompleks. Semi (2007:14) mengungkapkan pengertian menulis adalah suatu proses kreatif memindahkan gagasan ke dalam lambang-lambang tulisan. Nurgiantoro (1988:273) menyatakan bahwa menulis adalah aktivitas aktif produktif, yaitu aktivitas menghasilkan bahasa. Berdasarkan pendapat tersebut, dapat disimpulkan menulis merupakan kegiatan berupa penuangan ide/gagasan dengan kemampuan yang kompleks melalui aktivitas yang aktif produktif dalam bentuk simbol huruf dan angka secara sistematis sehingga dapat dipahami oleh orang lain.

Menurut Siswanto (2008:113) bahwa metode puisi atau struktur fisik puisi dibangun oleh perwajahan puisi, diksi, pengimajian, kata konkret dan majas atau bahasa figuratif, dan verifikasi. Hal senada juga menurut pendapat Waluyo (1995:71) bahwa unsur-unsur bentuk atau struktur fisik puisi dapat diuraikan dalam metode puisi yakni unsur estetik yang membangun struktur luar dari puisi. Unsurunsur itu dapat ditelaah satu persatu, tetapi unsur-unsur itu merupakan kesatuan yang utuh. Unsur-unsur itu ialah diksi, pengimajian, bahasa figuratif (majas), rima \& ritma, dan tata wajah puisi.

Kaitannya dengan penelitian ini, siswa diharapkan dapat menulis puisi dengan memperhatikan unsur-unsur puisi sehingga menghasilkan puisi yang indah dan bermakna.

\section{Media Pohon Pintar Berbasis Multimedia}

Molenda dan Russel (1990) mengungkapkan bahwa "media is a channel of communication. Derived from the latin word for "between", the term refers to anything that carries information between a source and a receiver". Hanick (1986) mendefinisikan media adalah sesuatu yang membawa informasi antara sumber (source) dan penerima (receiver) informasi. Dari beberapa pengertian tersebut dapat kita garis bawahi bahwa media adalah perantara dari sumber informasi ke penerima informasi, contohnya video, televisi, komputer, dan lain sebagainya.

Menurut kamus Bahasa Indonesia DepDikBud (1988:685,691) pengertian pohon adalah tumbuhan yang berbatang keras dan besar. Pengertian pintar yaitu pandai, cakap, cerdik, banyak akal, dan mahir dalam mengerjakan sesuatu. Berdasarkan hal tersebut, dapat disimpulkan bahwa pohon pintar adalah suatu alat permainan menggunakan macromedia flash CS 6 yang telah dibentuk semenarik mungkin sehingga dapat membantu anak dalam meningkatkan potensi, kecerdasan, dan kreativitas anak yang ada dalam diri anak agar berkembang secara optimal.

Keunggulan media pohon pintar berbasis multimedia ini adalah sebagai berikut.

a. Media ini menggunakan aplikasi macromedia flash didesain semenarik mungkin, bukan pohon manual yang terbuat dari ranting sehingga pembelajaran lebih menyenangkan.

b. Membantu mengungkapkan kata yang ada di pikiran siswa menjadi kalimat puisi. 
c. Memotivasi siswa untuk mengasah kemampuan menulis puisi.

d. Mudah menjalankannya karena sudah ada petunjuk di dalam aplikasi media pohon pintar.

e. Setiap pergantian slide lancar, tidak mengalami loading lambat (lemot).

f. Dapat digunakan pada segala pentium/tipe komputer. Adapun beberapa kelemahan dari media pohon pintar berbasis multimedia interaktif berikut ini.

a. Beberapa sekolah masih ada yang belum menunjang IT di sekolah, atau bahkan ada yang sudah mempunyai alat-alat komputer tetapi tidak dimanfaatkan.

b. Masih banyak siswa yang belum bisa mengoperasikan komputer/laptop dan memanfaatkan komputer dengan baik.

c. Sekolah yang dipergunakan untuk penelitian harus ada listrik dan peralatan komputer lengkap.

d. Dengan menggunakan aplikasi macromedia flash, rancangan media yang sudah jadi tidak akan bisa diedit kecuali membuat ulang dari awal.

Jadi pada penelitian ini, media pohon pintar bukanlah ditampilkan berupa pohon nyata yang terbuat dari batang pohon. Akan tetapi, pohon pintar ditampilkan dalam bentuk multimedia interaktif dengan bantuan macromedia flash. Pohon pintar dibuat semenarik mungkin dengan sejumlah buah yang berisi tema puisi dan berbagai kata yang dapat membantu siswa dalam merangkai kata puisi, serta materi puisi yang perlu dipelajari siswa untuk memahami puisi.

\section{Model Pembelajaran CIRC (Cooperative Integrated, Reading, and Composition)}

Model pembelajaran CIRC atau pembelajaran terpadu menurut pertama kali dikembangkan oleh Steven and Slavin (1981), dengan langkah-langkah:

1. Membentuk kelompok yang anggotanya 4 orang yang secara heterogen;

2. Guru memberikan wacana sesuai dengan topic pembelajaran;

3. Siswa bekerja sama saling membacakan dan menemukan ide pokok dan memberikan tanggapan terhadap wacana dan ditulis pada lembar kertas;

4. Mempresentasikan/membacakan hasil kelompok;

5. Guru memberikan penguatan;

6. Guru dan siswa bersama-sama membuat kesimpulan;

7. Penutup.

Langkah model pembelajaran CIRC dibagi menjadi beberapa fase (dalam Shoimin, 2014:53). Fase tersebut bisa diperhatikan dengan jelas sebagai berikut:
Tabel 1.

Sintaks Pembelajaran JUCAMA

\begin{tabular}{lll}
\hline No. & Fase & \multicolumn{1}{c}{ Kegiatan Guru } \\
\hline 1. & Orientasi & Melakukan apersepsi dan \\
& & pengetahuan awal siswa \\
& tentang materi yang akan \\
& diberikan, memaparkan \\
& tujuan pembelajaran yang \\
& akan dilakukan kepada \\
& siswa.
\end{tabular}

2. Organisasi Guru membagi siswa ke dalam beberapa kelompok, dengan memerhatikan keheterogenan akademik. Membagikan bahan bacaan tentang materi yang akan dibahas kepada siswa. Selain itu, menjelaskan mekanisme diskusi kelompok dan tugas yang harus diselesaikan selama proses pembelajaran berlangsung.

3. Pengenalan Mengenalkan tentang suatu konsep konsep atau istilah baru yang mengacu pada hasil penemuan selama eksplorasi. Pengenalan bisa didapat dari keterangan guru, buku paket, film, kliping, poster, atau media lainnya.

4. Publikasi Siswa mengomunikasikan hasil temuan-temuannya terhadap hasil karya teman, membuktikan, memeragakan hasil karya, baik kelompok maupun di depan kelas.

5. Penguatan dan Memberikan penguatan refleksi berhubungan dengan materi yang dipelajari melalui penjelasanpenjelasan ataupun memberikan contoh nyata dalam kehidupan seharihari. Selanjutnya, siswa pun diberi kesempatan untuk merefleksikan dan mengevaluasi hasil pembelajarannya.

\section{METODE PENELITIAN}

Rancangan dari penelitian ini merupakan jenis penelitian pengembangan atau research and development (R \& D), yaitu penelitian yang di akhir kegiatan 
menghasilkan produk berupa media yang dapat digunakan untuk mendukung pengembangan menulis puisi siswa kelas V SD pada pembelajaran bahasa Indonesia. Produk yang dihasilkan berupa media interaktif yang dikemas dalam bentuk judul-judul puisi dan pilihan kata dengan tampilan gambar atau visualisasi pohon berbuah. Judul puisi dan pilihan kata tersebut akan muncul ketika siswa memilih dan menekan tombol pada laptop atau komputer (bisa menggunakan mouse) yang berupa buah-buahan. Setiap buah memiliki judul puisi berbeda-beda dan pilihan kata sebanyak sepuluh kata. Untuk menulis puisi siswa diberikan waktu mengerjakan selama 45 menit. Alasan pemberian pilihan kata tersebut adalah untuk mempermudah dan memancing imajinasi siswa dalam merangkai kata puisi karena siswa SD masih kesulitan membuat kata-kata puisi yang sesuai dan tidak terlalu panjang. Untuk menentukan puisi yang terbaik adalah jika siswa membuat puisi dengan memperhatikan pengimajian, pengaturan kalimat, dan rima dan ritma puisinya teratur. Dengan demikian, media interaktif ini tidak hanya sekedar sebagai media bantu dalam menulis puisi melainkan juga sebagai alat yang dapat memotivasi siswa untuk lebih giat belajar.

Alur penelitian pengembangan penelitian ini mengikuti teori Four-D Metode. Menurut Thiagarajan dan Semmel (1975:5), metode pengembangan ini terdiri atas empat tahap pengembangan yaitu define (pendefinisian), design (perancangan), develop (pengembangan), dan disseminate (penyebaran). Data penelitian pengembangan media pohon pintar berbasis multimedia dalam kemampuan menulis puisi kelas V SD terdiri atas dokumen proses, kualitas, dan implementasi pengembangan media pohon pintar yang dijelaskan sebagai berikut:

a. Data proses pengembangan merupakan data dari hasil tahap pendefinisian dan tahap perancangan. Data hasil tahap pendefinisian yaitu:

1) Hasil observasi dari sekolah yang akan diteliti tentang pembelajaran bahasa Indonesia materi menulis puisi kelas V Sekolah Dasar.

2) Hasil analisis kebutuhan dan karakteristik siswa dalam pembelajaran Bahasa Indonesia materi menulis puisi.

3) Rumusan KI dan KD dari standar isi kurikulum 2013. Data hasil tahap perancangan berupa penilaian dari tim validator untuk draf I media pohon pintar.

b. Data kualitas media pohon pintar dari hasil tahap pengembangan yaitu skor nilai dari validator. Skor nilai hasil validasi draf II media pohon pintar untuk kelayakan isi, pembelajaran, dan teknik digunakan sebagai data untuk menjawab masalah kualitas media pohon pintar.

c. Data Implementasi dari tahap pengembangan media pohon pintar yaitu skor nilai dari data analisis guru, analisis siswa, hasil belajar siswa, respon guru dan siswa selama pembelajaran baik dari uji coba terbatas maupun uji coba luas.

Sumber data yang digunakan dalam penelitian terdiri atas data proses pengembangan, data kualitas, dan data implementasi media pohon pintar dengan 45 responden.Teknik pengumpulan data yang dilakukan dalam penelitian ini menggunakan observasi, validasi, angket, dan tes (berupa pre-test dan post-test).

Analisis data yang digunakan untuk penilaian media pohon pintar berbasis multimedia dalam model pembelajaran CIRC berdasarkan rumus rating scale (Riduwan, 2005:21). Analisis hasil belajar siswa dianalisis dengan menggunakan rumus uji-T untuk mengetahui perbedaan hasil belajar siswa pada pretest dan posttest. Persentase data angket respons siswa setelah menggunakan media pohon pintar berbasis multimedia dalam kemampuan menulis puisi yang diperoleh dan dihitung berdasarkan skala Guttman.

\section{HASIL PENELITIAN}

Hasil penilaian validator terhadap media pohon pintar dari segi kelayakan isi, pembelajaran, dan teknik pada revisi tahap II disajikan pada tabel berikut.

Tabel 2.

Rekapitulasi Hasil Penilaian Validasi Tahap II Media Pohon Pintar

\begin{tabular}{|c|c|c|c|c|c|}
\hline \multirow{2}{*}{ No. } & \multirow{2}{*}{$\begin{array}{c}\text { Kriteria } \\
\text { Media Pohon } \\
\text { Pintar }\end{array}$} & \multicolumn{4}{|c|}{ Penilaian Validator } \\
\hline & & P1 & $\mathbf{R 2}$ & $(\%)$ & Kategori \\
\hline 1. & Kelayakan isi & 38 & 3,8 & $95 \%$ & $\begin{array}{c}\text { Sangat } \\
\text { Baik }\end{array}$ \\
\hline 2. & $\begin{array}{l}\text { Kelayakan } \\
\text { pembelajaran }\end{array}$ & 34 & 3,8 & $94 \%$ & $\begin{array}{c}\text { Sangat } \\
\text { Baik }\end{array}$ \\
\hline 3. & $\begin{array}{l}\text { Kelayakan } \\
\text { teknik }\end{array}$ & 42 & 3,8 & $\begin{array}{c}95,4 \\
\%\end{array}$ & $\begin{array}{l}\text { Sangat } \\
\text { Baik }\end{array}$ \\
\hline \multicolumn{2}{|c|}{$\begin{array}{c}\text { Jumlah } \\
\text { Total Persentase } \\
(\%)\end{array}$} & \multicolumn{3}{|c|}{$94,8 \%$} & $\begin{array}{c}\text { Sangat } \\
\text { Baik }\end{array}$ \\
\hline
\end{tabular}

Berdasarkan tabel 2. penilaian validator terhadap media pohon pintar revisi tahap II mendapat skor diantaranya (1) skor penilaian validasi 38, rata-rata 3,8 dan persentase $95 \%$ dari validator isi; (2) skor penilaian validasi 34, rata-rata 3,8 dan persentase $94 \%$ dari validator pembelajaran; (3) skor penilaian validasi 42 , rata-rata 3,8 
dan persentase $95,4 \%$ dari validator teknik. Total skor penilaian dari ketiga validator adalah 114 dengan tingkat kelayakan $94,8 \%$.

Untuk kegiatan uji coba lapangan, subjeknya adalah siswa kelas V-E yang berjumlah 30 orang. Nilai KKM pada mata pelajaran Bahasa Indonesia kelas V adalah 75.

Tabel 3.

Daftar Nilai Hasil Belajar Uji Coba Lapangan

\begin{tabular}{|c|c|c|c|c|}
\hline \multirow[b]{2}{*}{ No. } & \multirow[b]{2}{*}{ Nama Siswa } & \multicolumn{2}{|c|}{ Nilai } & \multirow{2}{*}{$\underset{n}{\text { Ketuntasa }}$} \\
\hline & & $\begin{array}{c}\text { Pre- } \\
\text { test }\end{array}$ & $\begin{array}{l}\text { Post } \\
\text {-test }\end{array}$ & \\
\hline 1 & ADINDA CINDY A. & 80 & 86 & $\mathrm{~T}$ \\
\hline 2 & AHMAD TEGAR E. & 64 & 70 & TT \\
\hline 3 & ARENDA R. & 64 & 74 & TT \\
\hline 4 & ASSYIFA LUCKY P. & 76 & 80 & $\mathrm{~T}$ \\
\hline 5 & ATHIYYA A. & 90 & 94 & $\mathrm{~T}$ \\
\hline 6 & AVAN SEBASTIAN & 78 & 86 & $\mathrm{~T}$ \\
\hline 7 & BIMA DERI P. & 64 & 80 & $\mathrm{~T}$ \\
\hline 8 & CITRA NIKITA K. & 86 & 94 & $\mathrm{~T}$ \\
\hline 9 & DANANG SADEWO & 70 & 80 & $\mathrm{~T}$ \\
\hline 10 & $\begin{array}{l}\text { DELLA FIA } \\
\text { A'YUNIN }\end{array}$ & 80 & 88 & $\mathrm{~T}$ \\
\hline 11 & DINA TRI R. & 70 & 74 & $\mathrm{TT}$ \\
\hline 12 & FANSIS M. & 78 & 84 & $\mathrm{~T}$ \\
\hline 13 & FEBBY $\mathrm{K}$. & 84 & 92 & $\mathrm{~T}$ \\
\hline 14 & FERALDY RAVA N. & 68 & 82 & $\mathrm{~T}$ \\
\hline 15 & FRANDY HARI P. & 80 & 82 & $\mathrm{~T}$ \\
\hline 16 & MARSYA ARYBI L. & 86 & 90 & $\mathrm{~T}$ \\
\hline 17 & MOCH. ZULFIKAR & 72 & 78 & $\mathrm{~T}$ \\
\hline 18 & $\begin{array}{l}\text { MOCH. FATKHUR. } \\
\text { R }\end{array}$ & 82 & 94 & $\mathrm{~T}$ \\
\hline 19 & $\begin{array}{l}\text { MOCH. IRDIANTO. } \\
\mathrm{N}\end{array}$ & 76 & 78 & $\mathrm{~T}$ \\
\hline 20 & $\begin{array}{l}\text { M. IQBAL } \\
\text { ALFARIZI }\end{array}$ & 78 & 84 & $\mathrm{~T}$ \\
\hline 21 & M. IQBAL HAKIM & 84 & 90 & $\mathrm{~T}$ \\
\hline 22 & $\begin{array}{l}\text { M. RIANDRA } \\
\text { HALIM }\end{array}$ & 76 & 82 & $\mathrm{~T}$ \\
\hline 23 & NABILAH ALZENA & 82 & 90 & $\mathrm{~T}$ \\
\hline 24 & NADIA NUR FITRI & 78 & 88 & $\mathrm{~T}$ \\
\hline 25 & NATASYA IKA M. & 84 & 86 & $\mathrm{~T}$ \\
\hline 26 & PUTRI AYU W. & 80 & 84 & $\mathrm{~T}$ \\
\hline 27 & $\begin{array}{l}\text { ROHMAD } \\
\text { ADITYANI }\end{array}$ & 78 & 90 & $\mathrm{~T}$ \\
\hline 28 & RONNY H. & 80 & 82 & $\mathrm{~T}$ \\
\hline 29 & SITI KARINA N. & 74 & 86 & $\mathrm{~T}$ \\
\hline 30 & SRI AULIA M. & 78 & 84 & $\mathrm{~T}$ \\
\hline & Jumlah & 2320 & 253 & $\mathbf{T}=\mathbf{2 7}$ \\
\hline & Rata-rata & 77.33 & 84.4 & $\mathbf{T T}=\mathbf{3}$ \\
\hline & Persentase Tuntas & $73 \%$ & $\begin{array}{l}90 \\
\%\end{array}$ & - \\
\hline & $\begin{array}{l}\text { ) Persentase Tidak } \\
\text { Tuntas }\end{array}$ & $27 \%$ & $\begin{array}{l}10 \\
\%\end{array}$ & - \\
\hline
\end{tabular}

Pada saat kegiatan pre-test ada 8 siswa yang tidak tuntas belajar karena nilai mereka $\leq 75$, sedangkan 22 siswa dinyatakan tuntas belajar karena nilai mereka $\geq 75$. Secara klasikal, tingkat keberhasilan siswa sebelum menggunakan media pohon pintar berbasis multimedia dapat dihitung dengan cara jumlah siswa yang tuntas belajar 22, dibagi dengan jumlah siswa keseluruhan 30 , dikalikan $100 \%$ sehingga didapatkan hasil $73 \%$. Siswa yang tidak tuntas belajar dapat dihitung dengan jumlah siswa tidak tuntas 8 , dibagi dengan jumlah siswa keseluruhan 30, dikalikan $100 \%$ sehingga hasilnya $27 \%$ dan rata-rata nilai kelas $\mathrm{V}$-E adalah 77,33.

Dengan banyaknya siswa yang tidak lulus dan nilainya standar ketika kegiatan pre-test, maka pada kegiatan post-test peneliti menggunakan media pohon pintar berbasis multimedia. Ada peningkatan yang signifikan pada kegiatan pre-test dan post-test khususnya pada siswa yang nilai di bawah KKM maupun nilai standar tidak jauh dari KKM. Pada kegiatan post-test ini hanya ada 3 siswa yang tidak tuntas belajar, sedangkan 27 siswa nilainya $\geq 75$ sehingga dinyatakan tuntas belajar. Nilai tertinggi pada kegiatan post-test adalah 94 dan nilai terendah adalah 70. Secara klasikal, tingkat keberhasilan siswa setelah menggunakan media pohon pintar berbasis multimedia dapat dihitung dengan cara jumlah siswa yang tuntas belajar 27, dibagi dengan jumlah siswa keseluruhan 30, dikalikan $100 \%$ sehingga didapatkan hasil 90\%. Siswa yang tidak tuntas belajar dapat dihitung dengan jumlah siswa tidak tuntas 3, dibagi dengan jumlah siswa keseluruhan 30, dikalikan $100 \%$ sehingga hasilnya $10 \%$ dan rata-rata nilai kelas V-E adalah 84,4.Dari data secara umum, tingkat keberhasilan siswa kelas V-E dalam pembelajaran menulis puisi menggunakan media pohon pintar berbasis multimedia terdapat peningkatan sebanyak $17 \%$. Oleh karena itu, dapat disimpulkan bahwa media pohon pintar berbasis multimedia layak dan efektif digunakan untuk pembelajaran menulis puisi karena mampu memberikan peningkatan hasil belajar siswa dalam menulis puisi.

\section{DISKUSI HASIL PENELITIAN}

1. Proses Pembelajaran pada Penerapan Media Berbasis Multimedia

Menurut guru kelas V-E, dalam pembelajaran kita harus menyesuaikan media dengan materi dan media pohon pintar ini sangat menarik bagi siswa, informasi yang disajukan secara ringkas dengan adanya dukungan gambar, warna yang cerah, serta suara yang bisa membuat imajinasi siswa bertambah. Berdasarkan pendapat guru kelas V-E, peneliti dapat mengamati sebuah analisis pemahaman bahwa penerapan media pohon pintar dalam pembelajaran sudah dimengerti oleh siswa, dimana mereka sudah mengerti dan mengetahui apa maksud dari media pohon pintar dan bagaimana langkah-langkah penggunaannya. 
Dalam setiap media pembelajaran tentunya tidak lepas dari sebuah keunggulan dan kelemahan, sebagai analisis untuk mengetahui adanya perbedaan dengan media pembelajaran yang sudah ada, maka disini perlu analisis member gambaran tentang keunggulan dan kelemahan dari media pohon pintar.

Pernyataan tersebut sejalan dengan pendapat Philips (1997:12) yang menyatakan bahwa multimedia memiliki potensi untuk menciptakan suatu lingkungan multisensori yang mendukung cara belajar tertentu.

\section{Tidak Mudahnya Membuat Media Berbasis Multimedia}

Dalam media pohon pintar ini terdiri atas dua konsep yaitu menu kincir putar (berisi materi dan contoh puisi) dan icon buah pada pohon (berisi judul puisi dan pilihan kata). Kendala yang dihadapi saat pembuatan macromedia flash diantaranya pohon pintar dibuat dari flash CS 6, jika salah maka harus dibuat dari awal lagi; membuat link pada setiap slide; link untuk siswa dapat menulis pada media pohon pintar; dan membuat akses keluar dengan pilihan.

Pembuatan media interaktif ini membutuhkan waktu yang cukup lama karena harus dibuat menarik dan interaktif agar siswa menyukai pembelajaran menggunakan media pohon pintar. Dalam pembuatan media pohon pintar ini harus bisa menggunakan aplikasi macromedia flash secara mahir bukan otodidak. Jika secara otodidak maka hasilnya tidak maksimal dan kurang interaktif. Hal tersebut dapat teratasi karena bantuan ahli macromedia flash atau ahli grafis. Sebagaimana pendapat Sanjaya (2012:226) multimedia memberikan pilihan menu yang lebih beragam sehingga siswa sebagai pemakai media ini memiliki kesempatan untuk memilih menu pilihan yang lebih disukainya.

Dalam pembuatan media harus diperhatikan warna dan bentuknya. Warna yang digunakan adalah warna yang cerah dan tombol-tombol pada media menggunakan tombol yang lucu agar disukai anak-anak karena siswa tidak mungkin memakai warna dan bentuk yang formal. Gambar anak dan burung dipergunakan untuk mempermanis agar dinamis dan lucu, sedangkan kincir bergerak dipergunakan untuk memfokuskan pikiran siswa bahwa kincir itu bergerak. Ada beberapa hal yang menjadi kendala dalam pembuatan media sehingga membutuhkan waktu yang lama, diantaranya sebagai berikut:

1) Memasukkan motion tween pada beberapa obyek agar bisa bergerak;

2) Tulisan kedip dibuat dengan cara memasukkan banyak frame dan hanya frame ke-1 dan ke-3 yang diberi tulisan;
3) Kincir bergerak dan diksi yang bisa dipindah-pindah harus menggunakan action script untuk memberikan fungsi pada obyek.

\section{Hambatan dalam Implementasi Media untuk Kemampuan Menulis}

Sebuah media yang baru dikembangkan tentu memerlukan pemikiran yang seksama agar maksimal penggunaanya dan benar-benar dapat memberikan manfaat. Dengan adanya beberapa media pembelajaran yang menggunakan pohon pintar berbasis multimedia maka harus dimunculkan keistimewaan dari media yang akan dikembangkan. Agar media yang dikembangkan menjadi media yang beda di antara media-media yang sudah pernah ada, maka peneliti mempunyai inovasi baru untuk menggabung kedua media tersebut menjadi satu yaitu pengembangan media pohon pintar berbasis multimedia. Media yang dikembangkan akan diimplementasikan dengan model CIRC (Cooperative, Integrated, Reading and Composition). Untuk menyediakan media pembelajaran yang baik, peneliti meminta pendapat dari murid dan guru. Siswa yang dimintai pendapat adalah siswa kelas V-A dan V-E. Sedangkan faktor penghambat/kekurangan dari penggunaan media yang dikembangkan kebanyakan siswa menjawab seharusnya media pohon pintar berbasis multimedia petunjuknya dibuat lebih jelas lagi alur medianya.

Selain itu guru juga diberikan suatu lembar instrumen respon yang digunakan untuk mengetahui hambatan, faktor pendukung serta kelebihan dan kekurangan dari penggunaan media yang dikembangkan. Media yang dikembangkan memiliki beberapa kekurangan antara lain dari segi biaya relatif mahal, jika guru tidak dapat membuat sendiri dan meminta bantuan kepada ahli macromedia flash serta guru juga belum lancar menggunakan alat komputer. Selain itu poin yang perlu ditambah adalah jumlah buah lebih banyak dan bervariasi isinya, durasi mempelajari media ditambah lebih lama.

\section{SIMPULAN DAN SARAN}

Berdasarkan analisis data dan pembahasan hasil penelitian pengembangan media pohon pintar berbasis multimedia dalam pembelajaran CIRC diperoleh beberapa simpulan sebagai berikut.

1. Kegiatan pembelajaran yaitu pada proses pengembangan menggunakan model Four-D terdiri atas empat tahap pengembangan yaitu tahap pendefinisian meliputi analisis awal-akhir, analisis siswa, analisis konsep, analisis tugas, dan analisis perumusan tujuan pembelajaran menulis puisi; tahap perancangan meliputi desain awal media, penyusunan 
RPP, dan rancangan penerapan media (design); tahap pengembangan meliputi proses pembuatan isi media pohon pintar, proses pembuatan macromedia flash, proses pembuatan backsound, validasi ahli, revisi media tahap I, uji coba terbatas, revisi media tahap II, dan uji coba lapangan.

2. Kualitas media meliputi (1) validasi isi oleh ahli Bahasa Indonesia mendapatkan skor $95 \%$ dengan validitas sangat layak dan berkualitas; (2) validasi pembelajaran oleh ahli pembelajaran di SD mendapatkan skor $94 \%$ dengan validitas sangat layak dan berkualitas; (3) validasi teknik oleh ahli grafis mendapatkan skor $95,4 \%$ dengan validitas sangat layak dan berkualitas; (4) respon siswa mendapatkan skor $94,2 \%$ dengan kategori siswa senang menggunakan media pohon pintar; (5) aktivitas siswa mendapatkan skor $95,8 \%$ dengan kategori siswa sangat aktif;(6)respon guru mendapatkan skor 96,8\% dengan tingkat keberhasilan baik/positif; (7) aktivitas guru mendapatkan skor 96,6\% dengan tingkat keberhasilan sangat baik; (8) hasil belajar siswa pada saat pre-test mendapatkan skor $73 \%$, sedangkan hasil belajar pada saat post-test mendapatkan skor $90 \%$ dengan nilai ratarata kelas V-E adalah 84,4. Peningkatan hasil belajar siswa kelas V-E sebanyak $17 \%$.

3. Implementasi penggunaan media, faktor penghambat dalam penggunaan media membutuhkan tenaga ahli dalam proses pembuatannya. Cara penyimpanannya juga harus hati-hati karena berbentuk soft file, hindarkan file dari virus yang dapat merusak file media. Kedepannya, media ini akan terus dibenahi hingga bena-benar memenuhi kebutuhan siswa untuk memudahkan mereka dalam memahami pelajaran Bahasa Indonesia khususnya pembelajaran menulis puisi. Faktor pendukung penggunaan media ini dapat meringankan tugas guru pada saat menyampaikan materi menulis puisi, pemilihan gambar-gambar berbentuk animasi pohon berbuah, tata letak konsep media dan materi puisi dikemas secara sekuensial dapat meningkatkan minat siswa dalam menerima materi yang akan diajarkan oleh guru, serta dilengkapi dengan musik dan audio rekam sehingga belajar menjadi lebih semangat.

Atas dasar kesimpulan di atas, peneliti mengemukakan beberapa saran sebagai berikut.

1. Bagi siswa untuk membiasakan menggunakan alat teknologi baik komputer maupun internet untuk membantu proses pembelajaran di sekolah.

2. Bagi guru SD untuk menulis dan menyusun sendiri materi pembelajaran yang sesuai dengan kebutuhan peserta didiknya dengan menggunakan media yang terbaru, mengikuti perkembangan dunia pendidikan, serta membiasakan siswa untuk menggunakan peralatan teknologi masa kini agar tidak tertinggal dengan perkembangan teknologi.

3. Kepada peneliti lain pengembangan media, agar dalam penyusunan media perlu memperhatikan identifikasi materi dan media yang sesuai dengan lingkungan pemakai, menyesuaikan indikator dari $\mathrm{KI}$ dan $\mathrm{KD}$, membuat materi pembelajaran maupun media yang disampaikan secara sederhana namun tetap memuat KI dan KD.

\section{DAFTAR PUSTAKA}

Andrzejczak, N., Trainin, G., \& Poldberg, M. (2005). From image to text: Using images in the writing process. International Journal of Education \& the Arts, 6 (12). Retrieved [date] from http://ijea.asu.edu/v6n12/

Angelina, Evin Dwi. (2010). Penggunaan Media Pembelajaran "Pohon Pintar" dengan Teknik Permainan untuk Meningkatkan Keaktifan dan Penguasaan Konsep FPB dan KPK pada Siswa Kelas IV. Malang: Universitas Negeri Malang.

Aminuddin. (1990). "Pendekatan Tekstual dalam Analisis Bahasa Kias Puisi" dalam Sekitar Masalah Sastra. Malang: Yayasan Asih Asah Asuh.

Aminuddin. (2011). Pengantar Apresiasi Karya Sastra. Bandung: Sinar Baru Algensindo.

Arisni, Niken dkk. (2010). Pembelajaran Multimedia di Sekolah. Jakarta: Prestasi Pustakarya.

Arikunto, Suharsimi. (2006). Prosedur Penelitian: Suatu Pendekatan Praktik. Jakarta: PT Rineka Cipta.

Arsyad, Ashar. (2007). Media Pembelajaran. Jakarta: Raja Grafindo Persada.

Bailey, Stephen. (2011). Academic Writing: a Handbook For International Students. New York: Routledge.

Darmadi, Hamid. (2011). Metode Penelitian Pendidikan. Bandung: Alfabeta.

Elsevier Ltd. (2013). Factors Related the Utilization of Instructional Media. Education and TechnologyTASET, Universitesi, Turkey: Sakarya.

Gould, Erick, Robert D.Y, et.al. (1989). Act of Writing (McGraw-Hill English Language Series)

Harmer, Jeremy. (2007). How to Teach Writing. Malaysia: Stenton Associates.

Hunley, Tom C. (2007). Teaching Poetry Writing: A Fivecanon Approach. Great Britain: MPG Books. 
Kennedy, Mary M. (1998). Learning to teach writing: does teacher education make a difference?. New York: Teachers College, Columbia University.

Kennedy, William. (1966). How to Analyze Fiction. New York: Monarch Press.

Keraf, Gorys. (1985). Diksi dan Gaya Bahasa. Jakarta: Gramedia.

Leow, Fui-Theng dan Neo, Mai. (2014). Interactive Multimedia Learning: Innovating Classroom Education in a Malaysian University. The Turkish Online Journal of Educational Technology. From http://tojet.net/articles/v13i2/13211.

Malik, S. dan Agarwal, A. (2012). Use of Multimedia as a New Educational Technology Tool-A Study. International Journal of Information and Education Technology. From http://IJIET.2012.V2.181.

Maryanto, Joni. (2013). Peningkatan Keterampilan Menulis Puisi melalui Model Picture and Picture dengan Media Gambar pada Siswa Kelas V. Semarang: Universitas Negeri Semarang.

Masidjo, Ign. (1995). Penilaian Pencapaian Hasil Belajar Siswa Di Sekolah. Yogyakarta: Kanisius

McDonald, Christina R., dkk. (2002). Teaching writing: landmarks and horizons. United States of America: Southern Illinois University.

Moeliono, Anton M. (1982). Diksi atau Pilihan Kata. Jakarta: Bharata.

Nanulaitta. (2010). Pengembangan Media Pembelajaran Berbasis Multimedia pada Mata Pelajaran Bahasa Inggris Kelas XI IPA I SMA Negeri 2 Ambon.

Pradopo, Rakhmat Djoko. (2002). Pengkajian Puisi. Yogyakarta: Gadjah Mada University Press.

Raimes, Ann. (1983). Techniques in Teaching Writing. New York: Oxford University Press.

Riswanto dan Putra, Pebri Prandika. (2012). The Use of Mind Mapping Strategy in the Teaching of Writing. International Journal of Humanities and Social Science.

From http://ijhssnet.com/journals/Vol_2_No_21_Novemb er_2012/8

Sanaky, Hujair. (2011). Media Pembelajaran. Yogyakarta: Kaukaba.

Sanjaya, Wina. (2012). Media Komunikasi Pembelajaran. Jakarta: Prenada Media Group.

Semi, M. Atar. (1993). Metode Penelitian Sastra. Bandung: Angkasa.

Semi, M. Atar. (2007). Dasar-dasar Keterampilan Menulis. Bandung: Angkasa.
Shoimin, Aris. (2014). 68 Model Pembelajaran Inovatif dalam Kurikulum 2013. Yogyakarta: Ar-Ruzz Media.

Stanton, Robert. (1965). An Introduction to Fiction. New York: Holt, Rinehart and Watson, Inc.

Subana, M. dan Sunarti. (2000). Strategi Belajar Mengajar Bahasa Indonesia. Bandung: CV Pustaka Setia.

Sugiyono. (2007). Metode Penelitian Kuantitatif, Kualitatif dan $R \& D$. Bandung: Alfabeta.

Sugiyono. (2013). Metode Penelitian Kombinasi (Mixed Methods). Bandung: Alfabeta.

Suyitno, Amin. (2005). Mengadopsi Pembelajaran CIRC dalam Meningkatkan KeterampilanSiswa Menyelesaikan Soal Cerita. UNNES: Seminar Nasional F.MIPA.

Tarigan, Henry G. (1994). Menulis sebagai Suatu Keterampilan Berbahasa. Bandung: Angkasa.

Thiagarajan, S; Semmel, D.S; \& Semmel, M.I. (1974). Instructional Development for Training Teachers of Exceptional Children: A Sourcebook. Indiana: Indiana University.

Ummami, Adhe Zahrotul. (2013). Pengembangan Perangkat Pembelajaran Menulis Puisi Berbasis Model Pembelajaran Sinektik Menggunakan Media Kartu Analogi pada Siswa Kelas V Sekolah Dasar. Surabaya: Universitas Negeri Surabaya.

Waluyo, Herman J. (2010). Pengkajian dan Apresiasi Puisi. Salatiga: Widyasari.

Walker, Decker F. \& Hess, Robert D. (1984). Evaluation in courseware development. Dalam Walker, D. F. \& Hess, R. D., Instructional software: Principles and perspectives for design and use (pp 204-215). California: Wadsworth Publishing Company. 